\title{
Children's Recidivist who Conducted Criminal Act: Legal Psychology Perspective
}

\author{
Ratnawati \\ Faculty of Law, Universitas Hasanuddin, Indonesia. E-mail: ratnawati@unhas.ac.id
}

\begin{tabular}{l} 
ARTICLE INFO \\
\hline Keywords: \\
Children; Legal Psychology; \\
Recidivists \\
How to cite: \\
Ratnawati. (2020). \\
"Children's Recidivist Who \\
Conducted Criminal Act: \\
Legal Psychology \\
Perspective," Hasanuddin \\
Law Review, 6 (1): 142-148 \\
DOI: \\
10.20956/halrev.v6i1.1676 \\
\hline
\end{tabular}

\begin{abstract}
Children's social environment influences their psychological return to crimes, and it is a treatment or reward from friends which they consider right since they are encouraged to repeat their actions. The research is an empirical legal research. The results shows that The role of psychologists in Special Child Development Institutions is not optimal, due to limited resources. Furthermore, parents or families should actively supervise and limit the association of children as this will prevent them from returning to the social environment. This is because the environment encourages them to commit criminal acts. Also, the government should make provision for their development through the Ministry of Rights and human rights psychologists of any special institute for children's development.
\end{abstract}

Copyright ( 2020 HALREV. All rights reserved.

\section{Introduction}

A criminal and an action sanctions are usually given to children after committing crime. Criminal sanction prioritizes retaliation as a form of suffering, and it is deliberately inflicted on criminals. On the contrary, action sanction prioritizes their protection, guidance, or treatment. Meanwhile, the current research examined public support of parental responsibility for crimes children commit. ${ }^{1}$ Contrary to expectations, public support was found to be relatively low. According to Olof Kinberg, a Swedish Forensic Psychiatrist and Criminologist, that crime, in general, is the expression of an abnormality or immaturity of a perpetrator, which requires treatment rather than criminal. ${ }^{2}$ In addition, to safeguard the dignity of children, they are entitled to legal protection in the justice system and Article 7 paragraph (1) of Law Number 11 of 2012 on the Juvenile Justice System states that "the district court should

\footnotetext{
1 Brank, E. M., and Weisz, V. (2004). Paying for the crimes of their children: Public support of parental responsibility. Journal of Criminal Justice, 32(5): 465-475.

2 Gunarto, M. P. (2009). Sikap Memidana yang Berorientasi Pada Tujuan Pemidanaan. Mimbar Hukum, 21(1): 93-108.
} 
seek to diversify at the level of investigation, prosecution, and the examination of cases of Children," using the Restorative Justice approach. This Diversity protects children from the judicial process to avoid their stigmatization in conflict with the law since they are expected to return in a normal social environment to the children. Therefore, all parties need to be involved since the process aims to create Restorative Justice, both for the Child and the victim. Restorative Justice is a process of Diversity, that is, all parties involved in a particular crime jointly overcome the problem and create an obligation to make things better by involving victims, children, and the community in finding solutions to improve, reconcile, and obtain the reassurance that is not based on retaliation. However, these various efforts cannot stop the children from committing a crime again or to be called a recidivist.

The interview's results on November 4, 2019, at Class II Special Guidance Institution for Children (LPKA) Maros reported that a 17-year-old Child Recidivist Committing Crimes has stolen 4 times, and the offenses were committed together. After the first theft, he was acquitted of all charges for paying the cost of losses to the victim (Diversi). The child was placed in the LPKS (Social Welfare Organization) for 3 months to be corrected (Diversi) after the second theft. However, the third landed the child (theft of Article 363 of the Criminal Code) in a Criminal Prison at LPKA. Similarly, the fourth theft (theft of an Article 363 Criminal Code) ended in a Criminal Prison at LPKA. Special attention should be paid to the fact that children are the next generation in the country.

The research questions of, "what is the influence of intelligence and social factors on the psychological condition of a child to committing the same crime?" and, "what is the role of psychologists at the Special Child Development Institute in promoting recidivists of children that commit crimes?" we're further discussed

\section{Method}

The research is an empirical legal research. This study used a field research method by collecting data or information directly through question and answer to recidivists of children that commit criminal acts, and the Head of Guidance Section for Prisoners and Correctional Students, as well as through library research. Furthermore, a qualitative description approach through correct data collection was used to explain the truth of existing data by avoiding the use of incorrect ones.

\section{Characteristics of Legal Psychology Studies}

Understanding Legal Psychology is similar to the definition of legal matters relating to law. However, legal psychology is difficult to define since it has been studied by several experts with different views and reports. Also, it is a branch of science that studies law as an embodiment of the development of the human soul. Furthermore, Putwain and Sammons defined it as all forms of Psychological services performed by the law". ${ }^{3}$ Likewise, Bartol \& Bartol stated that studies related to aspects of human behavior in the legal process (such as witness memory, jury/judge decision making,

\footnotetext{
${ }^{3}$ Akhdhiat, H and Marliani, R. (2011). Psikologi Hukum. Bandung: CV Pustaka Setia. Bandung, p. 126.
} 
criminal behavior), and professional psychology provide assistance relating to the law".4

In addition, Achmad Ali classifies psychology study as empirical since it emphasizes the human determinants of the law such as the decisions of judges. This is the same as the study of legal sociology and anthropology, all of which are empirical studies. The study of Legal Psychology focuses on the individual as the unit of analysis. ${ }^{5}$ Therefore, in its perspective, the behavior of participants in the legal system is not only a result of their internal quality but also from the environment in which they work. The quality of the external environment and the stresses of the situation influences individual behavior6.

The study of Legal Psychology is primarily focused on the main participants in the law enforcement process such as eyewitnesses, suspects and/or defendants, crime victims, public prosecutors, lawyers, judges (and judges if using the jury system), and convicted persons. Therefore, it includes empirical studies, such as Psychological research on law, legal institutions, and people dealing with the law. In addition, it is typically a study that refers to social basis and theories as well as cognitive principles, to apply them to issues in the legal system such as eyewitness memory, jury decision making, investigation, and interviewer ${ }^{7}$.

The relationship between Psychology and law created the various types of Psychological approaches to Law. Craig Haney reported that this relationship can be seen by three methods, which are ${ }^{8}$

a. The relationship (psychology in the law) is the most visible application of Psychology to the legal system. In such a situation, jurists use psychologists and their knowledge for specific cases, such as having them testify about the defendant's mental state.

b. In this relationship (psychology and the law), Psychology is seen as a separate discipline that analyzes the legal system from a Psychological perspective and developing research and theories.

c. The relationship (psychology of the law), pays attention to the law as a determinant of behavior. How the law affects the community and vice versa ".

Achmad Ali explained four approaches in Legal Psychology, which are, ${ }^{9}$ psychology in law, which refers to its specific application; Psychology and law, used for Psychological research on defendants, police, lawyers, prosecutors, and judges, and Psychology of law, which refers to research on issues such as why to obey / or disobey certain laws, moral development, and public perceptions as well as attitudes towards various criminal sanctions, Forensic Psychology is the used in litigation.

\footnotetext{
4 Probowati, Y. (2008). "Peran Psikologi dalam Investigasi Kasus Tindak Pidana”, Indonesian Journal of Legal and Forensic Sciences, 1 (1): 26

5 Ali, A. (2002). Menguak Tabir Hukum: Suatu Kajian Filosofi dan Sosiologis, Jakarta: Gunung Agung, p. 13.

${ }^{6}$ Ibid.

7 Musakkir. (2013). Putusan Hakim yang Diskriminatif dalam Perkara Pidana Suatu Tinjauan Sosiologi Hukum dan Psikologi Hukum. Yogyakarta: Rangkang Education, p. 52.

8 Ibid, hlm.55-57.

9 Ali, A. Op. Cit, p. 10.
} 


\section{The Influence of Intelligence and Social Environment Factors on the Psychological Condition}

A child or a juvenile is someone that has not reached a certain age and is not yet am adult or married ${ }^{10}$. According to Nicholas McBala, the term child describes the period between birth and the beginning of maturity. This the time of life's development, which is characterized by limited ability including limitations to endanger others. ${ }^{11}$ The obtained results showed that the number of criminal Children throughout 2016-2018 at the special Guidance Institution for Class II Children Macros on November 4, 2019, amounted to 135 people. In addition, the number of criminal children in 2017 numbered 38 people, and the number of criminal children in 2018 numbered 54. Therefore, the number of criminal offenses recorded in 2016-2018 in LPKA Class II Maros was 227 people.

Data on the number of Child Recidivists in the 2016-2018 period was not well registered in the Maros Class II Special Guidance Institution, because there was no separate record in the registration book of Criminal Children categorized as Recidivists. The number of child recidivists that committed the repetition of crimes was 4 children, of which 2 were narcotics criminal recidivists. This was obtained through interviews with officers from Maria Class II Special Guidance Institution.

The term Recidivist come from the French context, which was initially carved from two Latin words, namely re and cado, and they are translated as again and to fall respectively. It means the tendency of a convicted criminal to repeatedly commit a crime. Such a person is repeatedly charged before the law on similar actions.

Recidivists are the reason for eliminating the diversion of children that conflict with the law as regulated in Article 7 paragraph (2) of Law Number 11 the Year 2012 concerning the Criminal Justice System for Children. Diversion is performed in terms of criminal acts committed, including:

a. Threatened with imprisonment of under 7 years, and (this provision refers to criminal law);

b. It is not a repetition of a criminal offense (this provision includes crimes committed by a child, both similar and unrelated acts, including offenses that are settled through Diversi).

The results of the interview showed that two factors caused children to repeat a crime, namely intelligence and social environment. This study uses the Psychology in Law approach (Psychology in law) which is applied to determine the influence of intelligence factors on children's behavior since crime is repeated and the influence of environmental factors on the child's psychology to repeat it.

According to Eisler "intelligence is the ability of a person to weigh and make decisions". 12 Furthermore, Wechsler stated that: "Early intelligence was the capacity to understand expressions and the will of the mind to overcome its challenges. On the other occasion, it was stated that intelligence is the ability to act in a focused manner, to think rationally, and to manage one's environment effectively. Therefore, it is the

10 Sambas, N. (2013), Peradilan Pidana Anak di Indonesia dan Instrumen Internasional Perlindungan Anak Serta Penerapannya, Yogyakarta: Graha Ilmu, p. 1.

11 Marliana. (2009), Peradilan Pidana Anak di Indonesia (Pengembangan Konsep Diversi dan Restoratif Justice), Bandung: PT Refika Aditama, p. 36.

12 Nashriana. (2011). Perlindungan Hukum Pidana Bagi Anak Di Indonesia. Jakarta: PT RajaGrafindo Persada, p. 36. 
ability to understand expressions, weigh, make decisions, and act, based on reason and rational. This is aimed at dealing effectively with their environment. ${ }^{13}$ Children that commit theft should know how to conduct these actions. Such knowledge is not immediately obtained just like that since it needs contact with the outside environment to acquire knowledge. Therefore, through sensation, the child can discover different behaviors that arise from the environment.

Children's knowledge about stealing can be obtained by interacting with their environment. As the leaders of tomorrow, they should not be ignored when they commit crimes. The need for maximum supervision to restore their psychological state, not to repeat their actions, and to obey the law for themselves and others is very important Correctional Institutions (LAPAS) and Special Guidance Institutions (LPKA) function to place children that have committed a criminal offense in detention. However, not all of them are placed in these institutions to receive guidance.

In practice, children are not counseled by criminal investigators on behavior to avoid since they are not affected by certain impulses to commit theft. Furthermore, they do not have the knowledge to prevent theft. The child returns to the environment because of free time that is not used for positive activities. Children tend to commit crimes in their leisure time, especially when they socialize in an unfavorable environment. Such environments are filled with friends that have anti-social attitudes, which means they enjoy rebellion and they like to hurt people as well as characterized with high $\operatorname{aggression}^{14}$.

According to Uri Bronfrenbrener, interaction between individuals and the environment is divided into three types, namely:

a. Microsystems are the environments in which people live, these connections include individual families, peers, schools, and neighborhoods. There are many direct interactions in the microsystem with social actors, such as parents, friends, and teachers. In the process of interaction the individual is not a passive recipient but actively participates in forming and building microsystem settings. Each gains experience from each activity, and plays a role in establishing interpersonal relationships with the microsystem environment consisting of parents, siblings, teachers, friends, and teachers.

b. Ecosystems are larger social systems where children do not engage in direct interaction but are influential on the development of character. Also, the subsystem consists of the workplace environment of parents, acquaintances of siblings, or other relatives, as well as regulations from the school.

c. Furthermore, it is the outermost layer system of the child's environment. Its subsystem consists of state ideology, government, tradition, religion, law, customs, culture, and so on. They influence the development of the child's character. Berk reported that the culture referred to in this sub-system is the pattern of behavior, beliefs, and all the products of a group passed down from one generation to another ${ }^{15}$.

13 Maftuh, (2015). “Intelegensi sebagai Faktor Belajar", Jurnal Studi Islam Miyah, Vol. 11 No. 2: 169

14 Sira, interview, Lembaga Pemasyarakatan Kelas I Makassar, 26 November 2019.

15 Mujahidah. (2015). "Implementasi Teori Ekologi Bronfenbrenner Dalam Membangun Pendidikan Karakter yang Berkualitas", Jurnal Lentera, 19 (2): 174-175. 
An environment that causes children to repeat their actions is usually filled with friends that often commit crimes. It is classified as a microsystem, meaning children interact directly with social agents that commit criminal acts. However, children are usually affected by their environment and they play an active role in influencing others, due to certain psychological conditions. Affected children do the same as the behavior obtained from their environment.

Motivation brings back the theft behavior in children since it is a psychological symptom in the form of an impulse that arises in a person consciously to take any action based on a specific purpose. It consists of intrinsic and extrinsic motivation. Intrinsic motivation is the urge or desire that is present in a person without the need for external stimulants. On the contrary, extrinsic motivation is accompanied by stimuli from an outsider. ${ }^{16}$

Children as Recidivists are motivated to repeat the crime since they are influenced by the invitation of their friends and will receive negative treatment when they do not commit the act. As an extrinsic motive, it means an invitation from friends to commit theft and will get negative treatment when they refuse, when the child gives in to the pressure, stealing will become an impulse that comes from outside and the act will be performed again.

As a social being, the child will always interact with other people to overcome their shortcomings such as loneliness. Giierveld defined loneliness as a situation in which someone experiences a relationship that is less pleasant and which is not integrated into the desired relationship. ${ }^{17}$ It is a subjective feeling of discomfort that exists because important criteria in social relationships are hampered. The inconvenience is quantitative, which means the feeling of not having friends. However, it is qualitative when the feeling about the constructed social fabric is modest.

Children should sometimes be left alone to handle their problems. They help children receive when they hang out with friends in a social environment makes them dependent when they have problems. Children are usually influenced by peer pressure, and they will do anything possible to support their friends since they do not want to get a negative reward in the form of sanctions.

Children's psychological problems such as criminal recidivists, which include difficulties in rejecting the invitation of their friends to commit Criminal Acts should be resolved. Counseling as a Guidance Program in its application has not been able to run optimally in solving the overall psychological problems of children, and it can be a trigger to repeat their actions. Furthermore, this effort could not be performed due to the absence of psychologist resources at LKPA Maros.

\section{Conclusion}

The impact of intelligence on children's psychological factors when committing a crime is that they do not take into account the effects of their actions. In addition, they do not know the consequences of not obtaining maximum guidance after committing a crime. The social environment that affects the psychological return is a treatment or reward given by friends concerning a crime that children consider right. Therefore, they are

16 Nashriana, Op.Cit, p. 35.

17 Dini, F.O and Herdina. (2014). "Hubungan antara Kesepian dengan Perilaku Agresif pada Anak Didik di Lembaga Pemasyarakatan Anak Blitar", Jurnal Psikologi Klinis dan Kesehatan Mental, 3 (3): 32. 
encouraged to commit the same offense. The Role of Psychologists in Special Child Development Institutions is not optimal, due to limited resources. Therefore, it is recommended to provide legal knowledge on the redistribution of children that commit crimes for them to understand the behavior that violates the law. Furthermore, parents or families should actively supervise and limit the association of children as this will prevent them from returning to the social environment. This is because the environment encourages them to commit criminal acts. Also, the government should make provision for their development through the Ministry of Rights and human rights psychologists of any special institute for children's development.

\section{References}

Akhdhiat, H and Marliani, R. (2011). Psikologi Hukum. Bandung: CV Pustaka Setia. Bandung.

Ali, A. (2002). Menguak Tabir Hukum: Suatu Kajian Filosofi dan Sosiologis, Jakarta: Gunung Agung.

Brank, E. M., \& Weisz, V. (2004). Paying for the crimes of their children: Public support of parental responsibility. Journal of Criminal Justice, 32(5), 465-475.

Dini, F.O and Herdina. (2014). "Hubungan antara Kesepian dengan Perilaku Agresif pada Anak Didik di Lembaga Pemasyarakatan Anak Blitar", Jurnal Psikologi Klinis dan Kesehatan Mental, 3 (3): 32.

Gunarto, M. P. (2009). Sikap Memidana yang Berorientasi Pada Tujuan Pemidanaan. Mimbar Hukum, 21(1), 93-108.

Maftuh, (2015). “Intelegensi sebagai Faktor Belajar", Jurnal Studi Islam Miyah, Vol. 11 No. 2: 169.

Marliana. (2009), Peradilan Pidana Anak di Indonesia (Pengembangan Konsep Diversi dan Restoratif Justice), Bandung: PT Refika Aditama.

Mujahidah. (2015). “Implementasi Teori Ekologi Bronfenbrenner Dalam Membangun Pendidikan Karakter yang Berkualitas", Jurnal Lentera, 19 (2): 174-175.

Musakkir. (2013). Putusan Hakim yang Diskriminatif dalam Perkara Pidana Suatu Tinjauan Sosiologi Hukum dan Psikologi Hukum. Yogyakarta: Rangkang Education.

Nashriana. (2011). Perlindungan Hukum Pidana Bagi Anak di Indonesia. Jakarta: PT RajaGrafindo Persada.

Probowati, Y. (2008). "Peran Psikologi dalam Investigasi Kasus Tindak Pidana", Indonesian Journal of Legal and Forensic Sciences, 1 (1): 26.

Sambas, N. (2013), Peradilan Pidana Anak di Indonesia dan Instrumen Internasional Perlindungan Anak Serta Penerapannya, Yogyakarta: Graha Ilmu.

\section{Conflict of Interest Statement:}

The author(s) declares that the research was conducted in the absence of any commercial or financial relationships that could be construed as a potential conflict of interest.

Copyright (C) 2020 HALREV. All rights reserved. 